\title{
PENGARUH TENAGA KERJA, IPM DAN KEMISKINAN TERHADAP PERTUMBUHAN EKONOMI KABUPATEN KOTA DI JAWA TIMUR TAHUN 2014-2018
}

\author{
Budi Prayitno \\ Renta Yustie \\ Fakultas Ekonomi dan Bisnis, Universitas Wijaya Kusuma Surabaya \\ email: budiprayitno@uwks.ac.id
}

\begin{abstract}
The progress and development of a region's economic development can be measured using economic growth. Economic growth can be influenced through labor, HDI, and poverty so that it can have an impact on the economic growth of a region. This study uses independent variables are labor, HDI, and poverty. Dependent variable in this study is economic growth. Times serries this study are 2014-2018 and cross section this study in district and city at Jawa Timur Province. This study used panel methode and used multiple linier regresion. The result from the study is aimed variables labor, HDI, and poverty have a significan impact to economic growth. Economic Growth can grows well if labor and HDI are in positive condition, and poverty is in a decreasing condition.
\end{abstract}

Keywords: labor, human development index, poverty, growth

\section{PENDAHULUAN}

Tenaga kerja sebagai penggerak kegiatan perekonomian dibekali dengan keahlian dan keterampilan untuk mempermudah dalam kegiatan produksi, distribusi dan kegiatan proses produksi lainnya. Tenaga kerja tidak hanya dilihat dari kuantitas yaitu jumlahnya saja tetapi dilihat pula dari sudut kualitas yaitu mutu seperti tingkat pendidikan dan kesehatannya.

Sektor perekonomian memiliki tenaga kerja dan modal berupa mesin dan peralatan dalam kegiatan proses produksi barang dan jasa. Tenaga kerja jika digabungkan dengan mesin dan peralatan maka dapat menghasilkan output yang lebih besar jumlahnya, karena produktivitas menjadi lebih tinggi dan kualitas juga menjadi lebih baik. Perkembangan tenaga kerja yang diwakili oleh Indeks Pembangunan Manusia (IPM) memegang peranan penting dalam perekonomian. Indeks Pembangunan Manusia (IPM) melalui peningkatan kapabilitas penduduk melalui pendidikan dan kesehatan manusia untuk mencapai kesejahteraan masyarakat dan tingkat pertumbuhan ekonomi yang diharapkan.

Indeks Pembangunan Manusia merupakan indeks yang memiliki 3 (tiga) dimensi dasar yaitu pendidikan (pengetahuan), kesehatan (umur panjang dan hidup sehat), kesejahteraan (standar hidup layak). Indeks Pembangunan Manusia merupakan indikator penting untuk mengukur keberhasilan dalam upaya membangun kualitas hidup manusia (masyarakat/penduduk).

Terkait dengan kualitas hidup manusia (masyarakat/penduduk) memiliki dampak pada kemiskinan. Upaya penurunan tingkat kemiskinan merupakan program atau kegiatan kerjasama antara pemerintah, swasta dan masyarakat. Pemerintah daerah kabupaten/kota bertanggung jawab atas perencanaan dan pelaksanaan program dan kebijakan, sedangkan masyarakat diperlukan kesadarannya untuk meningkatkan kualitas dan produktivitasnya.

Kendala dalam mengatasi kemiskinan masih dihadapi baik dari sisi pengelolaan maupun ketidakpastian sasaran. Pemulihan sebagai upaya menurunkan tingkat kemiskinan bersifat jangka panjang dengan cara penguatan kelembagaan, pengembangan sarana dan prasarana ekonomi desa, peningkatan kemampuan sumberdaya manusia. Pertumbuhan ekonomi yang tinggi dapat mengurangi jumlah penganggur dan mengatasi kemiskinan, melalui perluasan kesempatan kerja dan penciptaan lapangan pekerjaan baru serta pemerataan distribusi pendapatan sektoral dan perorangan untuk mengatasi ketimpangan kesejahteraan dan kemiskinan. Perbedaan pertumbuhan ekonomi yang terjadi sebagai konsekuensi dari pembangunan yang terkonsentrasi, beberapa daerah mengalami kemajuan cukup cepat, sementara itu beberapa 
daerah lain mengalami kemajuan yang lambat dalam hal kegiatan ekonomi dan pendapatan masyarakatnya. Hal ini disebabkan kurangnya sumberdaya-sumberdaya yang dimiliki dan kurangnya potensi dalam mengelola sumberdaya tersebut serta kurang tersedianya fasilitas yang mendukung pembangunan daerah (BPS Provinsi Jawa Timur, 2010).

Keberhasilan pembangunan suatu daerah dapat dilihat dari tingkat pertumbuhan ekonomi di daerah tersebut. Semakin tinggi tingkat pertumbuhan ekonomi suatu daerah bisa menjadi indikator tingginya tingkat keberhasilan pembangunan di daerah tersebut serta kondisi perekonomian yang kuat. Semakin rendah tingkat pertumbuhan ekonomi suatu daerah bisa menunjukkan rendahnya tingkat keberhasilan pembangunan di daerah tersebut serta kondisi perekonomian yang kurang. Perhitungan perekonomian suatu daerah diperoleh dengan cara menghitung semua jenis barang dan jasa yang dihasilkan dari aktivitas ekonomi oleh daerah tersebut dalam kurun waktu tertentu yang disebut dengan Produk Domestik Regional Bruto (PDRB).

\section{Rumusan Masalah}

Apakah tenaga kerja, IPM dan kemiskinan berpengaruh secara parsial terhadap pertumbuhan ekonomi kabupaten dan kota di Jawa Timur tahun 2014 - 2018 ?

Apakah tenaga kerja, IPM dan kemiskinan berpengaruh secara simultan terhadap pertumbuhan ekonomi kabupaten dan kota di Jawa Timur tahun 2014 - 2018?

\section{Teori Pertumbuhan Ekonomi Rostow}

Ahli ekonomi W.W. Rostow memakai pendekatan sejarah dalam menjelaskan proses perkembangan ekonomi yang dibedakan dalam lima tahap pertumbuhan ekonomi. Tahapantahapan tersebut terdiri dari: (1) Masyarakat Tradisional, (2) Prasyarat Tinggal Landas, (3) Tinggal Landas, (4) Dorongan Menuju Kedewasaan, dan (5) Konsumsi Massa BesarBesaran

Rostow juga mengartikan pembangunan ekonomi sebagai suatu proses yang menyebabkan perubahan dalam masyarakat meliputi perubahan politik, struktur sosial, nilai sosial dan struktur kegiatan ekonomi.

\section{Teori Kemiskinan Todaro}

Todaro dan Smith (1998:7) menyatakan keterbelakangan penduduk negara berkembang terutama disebabkan karena tingkat pertumbuhan penduduk yang tinggi dan penyerapan tenaga kerja yang rendah, menyebabkan produktivitasnya rendah sehingga pendapatan rendah, hal ini mengakibatkan rendahnya standar kualitas hidup atau rendahnya tingkat hidup.

Tingkat hidup yang rendah ditandai dengan (1) kemiskinan, (2) kesehatan yang buruk dan tidak memadai, dan (3) pendidikan dan layanan masyarakat yang rendah. Hal tersebut berakibat pada (1) penghargaan diri yang rendah dan (2) kebebasan yang terbatas. Todaro dan Smith (1988) menunjukkan adanya hubungan antara kemiskinan dengan keterbelakangan dengan beberapa aspek ekonomi dan aspek non ekonomi. Tiga komponen utama sebagai penyebab kemiskinan masyarakat yaitu (1) rendahnya taraf hidup, (2) rendahnya rasa percaya diri, dan (3) terbatasnya kebebasan. Ketiga sebab tersebut memiliki hubungan timbal balik. Pilar utama kajian kemiskinan paling tidak didasarkan atas pertimbangan-pertimbangan budaya, ekonomi dan sosial. Perspektif budaya penduduk miskin yang hidup miskin adalah lebih mudah hidup tanpa pendapatan daripada harus bekerja keras memperoleh pendapatan.

\section{Teori Indeks Pembangunan Manusia (IPM)}

Indeks Kualitas Hidup (Physical Quality of Life Index) atau yang lebih dikenal dengan Indeks Pembangunan Manusia (IPM) adalah indeks komposit yang terdiri dari 3 komponen yaitu tingkat pendidikan, kesehatan, kesejahteraan masyarakat yang digunakan untuk mengukur tingkat pembangunan manusia. Pendidikan memiliki peranan penting dalam rangka proses pendewasaan dan meningkatkan kecerdasan masyarakat sehingga dapat menciptakan manusia yang tangguh, berwawasan luas, memiliki keterampilan dan pengetahuan yang dapat menumbuhkan sikap pengembangan pada diri maupun masyarakat.

Kesehatan merupakan faktor penting dalam pembentukan kualitas sumberdaya manusia yang berkualitas dan bermutu. Kesehatan dapat diukur melalui indikator utama yaitu angka harapan hidup serta indikator penunjang antara lain, fasilitasfasilitas kesehatan yang tersedia, angka kematian, tingkat morbiditas, tingkat fertilitas, dan hari-hari sakit. Kesejahteraan masyarakat menyatakan bahwa masyarakat sejahtera apabila memenuhi syarat-syarat sebagai berikut: (1) memiliki tingkat pendidikan yang tinggi dan bermutu dengan indikator (tingkat pendidikan, tingkat melek huruf dan tingkat partisipasi pendidikan), (2) memiliki 
tingkat kesehatan yang baik dengan indikator antara lain (fasilitas-fasilitas kesehatan, tingkat morbiditas, hari-hari sakit, tingkat fertilitas), dan (3) tingkat kesempatan kerja yang tinggi dibarengi dengan tingkat partisipasi angkatan kerja yang tinggi dan terserapnya tenaga kerja oleh lapangan kerja.

\section{Teori Tenaga Kerja John Stuart Mill}

Tanah dan tenaga kerja adalah faktor produksi dari alam sedangkan modal sebagai persediaan yang dikumpulkan dari produk-produk tenaga kerja sebelumnya. Peningkatan kesejahteraan dilakukan bila tanah dan modal mampu meningkatkan produksi lebih cepat dibanding angkatan kerja. Kesejahteraan dapat diperoleh melalui peralatan, mesin dan ketrampilan angkatan kerja. Tenaga kerja produktif dapat menciptakan kesejahteraan dan akumulasi modal. Laju akumulasi modal merupakan fungsi dari bagian angkatan kerja yang dipekerjakan secara produktif. Laba yang diterima dengan mempekerjakan tenaga kerja tidak produktif hanya sebagai pengalihan pendapatan, tenaga kerja tidak produktif tidak menghasilkan kesejahteraan atau pendapatan. Analisis untuk mengatasi kemiskinan dengan pengendalian pertumbuhan penduduk golongan kelas pekerja, dimana pertumbuhan jumlah tenaga kerja produktif yang bekerja atas dasar upah.

\section{Penelitian Sebelumnya}

Penelitian yang dilakukan oleh Sajid Anwar (1998) mengenai peningkatan tenaga kerja dan pengurangan pengangguran di Australia tergantung dari tingkat upah, harga barang atau output tenaga kerja dan pengeluaran pemerintah untuk atasi pengangguran dengan penyediaan lapangan pekerjaan dan perluasan kesempatan kerja.

Penelitian yang dilakukan oleh Randall (2007) di Jepang, menjelaskan bahwa pengeluaran pemerintah daerah bidang pendidikan dan pembangunan infrastruktur digunakan untuk memperbaiki kualitas tenaga kerja dan mengurangi pengangguran serta perbaikan upah untuk mengurangi kemiskinan, mengatasi ketimpangan pendapatan yang berkaitan pada terbentuknya kesejahteraan masyarakat, hasilnya menunjukkan, bahwa dengan peningkatan pengeluaran pemerintah daerah dapat mengurangi pengangguran dan mengatasi kemiskinan serta berkurangnya ketimpangan pendapatan.

Penelitian yang dilakukan oleh Werner (2007) di Brazil menjelaskan untuk meningkatkan pemerataan distribusi pendapatan, mengatasi kemiskinan dan meningkatkan pertumbuhan ekonomi maka yang dilakukan pemerintah daerah adalah meningkatkan pengeluaran pemerintah daerah untuk pendidikan, pembangunan infrastruktur, kesejahteraan sosial dan ketenagakerjaan, hasil penelitian dapat menurunkan angka koefisien gini, mengurangi persentase penduduk miskin dan meningkatkan pertumbuhan ekonomi.

\section{Hipotesis} adalah:

Hipotesis yang diajukan dalam penelitian ini

1. Variabel tenaga kerja, IPM dan kemiskinan memiliki pengaruh secara parsial terhadap pertumbuhan ekonomi kabupaten dan kota di Jawa Timur Tahun 2014-2018.

2. Variabel tenaga kerja, IPM dan kemiskinan memiliki pengaruh secara simultan terhadap pertumbuhan ekonomi kabupaten dan kota di Jawa Timur Tahun 2014-2018.

\section{Model Analisis}

Model analisis yang digunakan dalam penelitian ini yaitu:

$$
P E_{i t}=\beta_{o}+\beta_{1} T_{i t}+\beta_{2} I P M_{i t}+\beta_{3} K_{i t}+e_{i t}
$$

Keterangan:

$\mathrm{PE}=$ Pertumbuhan Ekonomi kabupaten dan kota di Jawa Timur tahun 2014-2018

TK = Tenaga Kerja kabupaten dan kota di Jawa Timur tahun 2014-2018

IPM = IPM kabupaten dan kota di Jawa Timur tahun 2014-2018

$\mathrm{K}=$ Kemiskinan kabupaten dan kota di Jawa Timur tahun 2014-2018

Bo $=$ Intersep atau Konstanta Regresi

$\beta=$ Tingkat elastisitas kontribusi variabel bebas terhadap variabel terikat

= Errorterm

$=$ Cross section

$=$ Time series

\section{METODE PENELITIAN \\ Pendekatan Penelitian}

Pendekatan yang digunakan dalam penelitian ini adalah pendekatan metode kuantitatif dan pendekatan deskriptif. Pendekatan dengan menggunakan metode kuantitatif adalah penelitian yang menitikberatkan pada pengujian hipotesis dengan data yang terukur sehingga menghasilkan kesimpulan yang dapat digeneralisasikan. Pendekatan deskriptif digunakan untuk membahas intepretasi lebih lanjut dari hasil penelitian ini yang 
diperoleh dalam bentuk analisis kuantitatif, sehingga pada akhirnya dapat diperoleh kesimpulan dalam penelitian yang dilakukan (Sugiyono, 2012).

\section{Populasi dan Sampel}

Populasi menurut Sugiyono (2012) merupakan wilayah generalisasi yang terdiri atas obyek dan subyek yang mempunyai kualitas dan karakteristik tertentu untuk dipelajari kemudian ditarik kesimpulan. Populasi dalam penelitian ini menggunakan kabupaten dan kota di Jawa Timur dalam kurun waktu selama 5 tahun meliputi tahun 2014-2018.

Sampel merupakan bagian dari jumlah dan karakteristik yang dimiliki oleh populasi (Sugiyono, 2012). Sampel dalam penelitian ini menggunakan kabupaten dan kota di Jawa Timur. Penggunaan tahun penelitian meliputi tahun 2014 2018.

\section{Jenis dan Sumber Data}

Jenis data yang digunakan dalam penelitian ini meliputi Data Sekunder yang bersumber dari:

1. BPS Jawa Timur

2. Dinas Tenaga Kerja dan Transmigrasi Provinsi Jawa Timur

3. Dinas Kependudukan dan Pencatatan Sipil Provinsi Jawa Timur

\section{Identifikasi Variabel}

Identifikasi variabel yang digunakan pada penelitian ini meliputi variabel:

1. Variabel Bebas: (a) Tenaga Kerja, (b) IPM, dan (c) Kemiskinan.

2. Variabel Terikat: Pertumbuhan Ekonomi.

\section{Definisi Operasional Variabel}

Definisi Operasional Variabel pada penelitian ini adalah:

1. Tenaga Kerja: Tenaga Kerja usia produktif dalam satuan jiwa dan persen.

2. IPM: Indeks Pembangunan Manusia dalam satuan persen.

3. Kemiskinan: Jumlah penduduk miskin dalam satuan jiwa dan persen.

4. Pertumbuhan Ekonomi: Angka pertumbuhan ekonomi dalam satuan persen

\section{Teknik Analisis}

\section{Metode Data Panel}

Metode data panel adalah kombinasi dari data time series dan cross section dengan menggabungkan data time series dan cross section (pooling) maka jumlah observasi bertambah secara signifikan.

Terdapat tiga metode yang dapat digunakan untuk data panel. Metode yang pertama adalah pendekatan Pooled Least Square (PLS) yang secara sederhana menggabungkan seluruh data time series dan cross section kemudian mengestimasi model dengan menggunakan metode Ordinary Least Square (OLS). Metode yang kedua adalah pendekatan Fixed Effect Model (FEM) yang memperhitungkan kemungkinan peneliti menghadapi masalah omitted variables yang mungkin membawa perubahan pada intercept time series atau cross section. Metode yang ketiga adalah pendekatan Random Effect Model (REM) yaitu berupa pendekatan efek acak yang memperbaiki efisiensi proses least square dengan memperhitungkan error dari cross section dan time series.

Model data panel untuk masing-masing teknik regresi adalah sebagai berikut:

a. Pooled Least Square

$$
\mathrm{Y}_{\mathrm{it}}=\beta_{1}+\beta_{2}+\beta_{3} \mathrm{X}_{3 \mathrm{it}}+\ldots .+\beta_{\mathrm{n}} \mathrm{X}_{\mathrm{nit}}+\mathrm{U}_{\mathrm{it}}
$$

b. Fixed Effect Model

$Y_{\text {it }}=\alpha_{1}+\alpha_{2} D_{2}+\ldots .+\alpha_{n} D_{n}+\beta_{2} X_{2 i t}+\ldots .+$

$\beta_{\mathrm{n}} X_{\mathrm{nit}}+\mathrm{U}_{\mathrm{it}}$

c. Random Effect Model

$$
\mathrm{Y}_{\mathrm{it}}=\beta_{1}+\beta_{2} \mathrm{X}_{2 \mathrm{it}}+\ldots .+\beta_{\mathrm{n}} \mathrm{X}_{\mathrm{nit}}+\varepsilon_{\mathrm{it}}+\mathrm{U}_{\mathrm{it}}
$$

Secara umum dengan menggunakan data panel akan menghasilkan intersep dan slope koefisien yang berbeda pada setiap wilayah dan setiap periode waktu tertentu. Mengestimasi persamaan model regresi dalam bentuk linier akan sangat tergantung dari asumsi yang kita buat tentang intersep dan koefisien slope dari variabel gangguannya. Beberapa kemungkinan yang akan muncul yaitu (Widarjono, 2007:251):

1. Diasumsikan intersep dan slope adalah tetap sepanjang waktu dan individu (wilayah) dan perbedaan intersep dan slope dijelaskan oleh variabel gangguan.

2. Diasumsikan slope adalah tetap tetapi intersep berbeda antar individu.

3. Diasumsikan slope tetap tetapi intersep berbeda baik antar waktu maupun antar individu.

4. Diasumsikan intersep dan slope berbeda antar individu.

5. Diasumsikan intersep dan slope berbeda antar waktu dan antar individu

Penelitian menggunakan data panel karena data panel mempunyai beberapa keunggulan yaitu

(1) data panel mampu memperhitungkan 
heterogenitas individu secara eksplisit, (2) data panel mendasarkan diri pada observasi cross section yang berulang-ulang sehingga metode data panel cocok untuk digunakan sebagai study of dynamic adjustment, (3) tingginya jumlah observasi berimplikasi pada data yang lebih informatif, variatif dan peningkatan derajat kebebasan (degree of freedom) sehingga dapat diperoleh hasil estimasi yang lebih efisien, (4) data panel dapat digunakan untuk mempelajari modelmodel perilaku yang kompleks, dan (5) data panel dapat meminimalisir bias yang mungkin ditimbulkan.

\section{Pemilihan Model Estimasi Pada Data Panel}

Pemilihan model estimasi pada data panel menggunakan tiga pendekatan yaitu:

1. Pendekatan Pooled Least Square (PLS) yaitu pendekatan yang menggabungkan seluruh time series dan cross section kemudian mengestimasi model dengan gunakan metode Ordinary Least Square (OLS).

2. Pendekatan Fixed Effect Model (FEM) yaitu pendekatan yang terdapat perhitungan ommited variable dimana ommited variable ini memungkinkan adanya perubahan pada time series dan cross section.

3. Pendekatan Random Effect Model (REM) yaitu pendekatan yang berupa model untuk memperbaiki efisiensi proses least square dengan memperhatikan error dari time series dan cross section.

\section{Pengujian Statistik}

Uji R ${ }^{2}$

Kegunaan uji $\mathrm{R}^{2}$ adalah untuk menunjukkan apakah variabel independennya dapat menerangkan variabel dependennya dengan baik, nilai $\mathrm{R}^{2}$ berkisar antara $0-1$. Suatu model regresi apabila nilai $\mathrm{R}^{2}$ semakin dekat dengan angka 1 maka semakin kuat variabel bebas (independent) dalam menerangkan variasi variabel tergantung (dependent) dan sebaliknya semakin dekat dengan angka 0 maka semakin lemah variabel bebas (independent) dalam menerangkan variasi variabel tergantung (dependent).

\section{Uji F}

Uji $F$ dipakai untuk melihat pengaruh variabel-variabel bebas secara bersama-sama (simultan) dalam mempengaruhi variabel tidak bebas, dimana:

$$
\mathrm{H}_{0}: \beta_{1}=\beta_{2}=\beta_{3}=\beta_{4}=0
$$

Artinya tidak ada pengaruh antara variabel bebas dengan variabel tergantung

$\mathrm{H}_{1}: \beta_{1} \neq \beta_{2} \neq \beta_{3} \neq \beta_{4} \neq 0$

Artinya ada pengaruh antara variabel bebas dengan variabel tergantung

Jika $\mathrm{F}_{\text {hitung }}<\mathrm{F}_{\text {tabel }}$ maka hipotesis $\left(\mathrm{H}_{0}\right)$ diterima dan hipotesis alternatif $\left(\mathrm{H}_{1}\right)$ ditolak. Bila terjadi keadaan demikian maka dapat dikatakan bahwa variasi dari model regresi tidak berhasil menerangkan variabel bebasnya.

Sebaliknya, jika $F_{\text {hitung }}>F_{\text {tabel }}$ maka dapat dikatakan hipotesis nol $\left(\mathrm{H}_{0}\right)$ ditolak dan hipotesis alternatif $\left(\mathrm{H}_{1}\right)$ diterima. Bila terjadi demikian maka dapat dikatakan bahwa variasi dari model regresi dapat menerangkan variabel bebas.

Uji t

Pengujian ini merupakan suatu uji hipotesis terhadap koefisien regresi parsial yang digunakan untuk melihat pengaruh masing-masing variabel bebas secara individu atau parsial terhadap variabel tergantungnya. Adapun langkah-langkah adalah sebagai berikut:

$\mathrm{H}_{0}: \beta_{1}=0$

Artinya tidak ada pengaruh antara variabel bebas dengan variabel tergantung

$\mathrm{H}_{1}: \beta_{1} \neq 0$

Artinya terdapat pengaruh antara variabel bebas dengan variabel tergantung

Apabila $t_{\text {hitung }}<\mathrm{t}_{\text {tabel }}$ maka hipotesis nol $\mathrm{H}_{0}$ diterima dan hipotesis alternatif $\mathrm{H}_{1}$ ditolak artinya model yang digunakan kurang baik dimana variabel bebas tidak dapat menerangkan variabel terikatnya atau tidak signifikan. Sebaliknya jika $t_{\text {hitung }}>t_{\text {tabel }}$ maka dapat dikatakan bahwa variabel bebas dapat menerangkan variabel terikatnya atau signifikan.

\section{PEMBAHASAN}

Dari hasil pengolahan data, diperoleh persamaan daalam penelitian ini, yaitu:

$$
\begin{aligned}
\mathrm{PE}_{\mathrm{it}}= & 23.063+0.248169 \mathrm{TK}+0.285959 \mathrm{IPM} \\
& -0.229780 \mathrm{~K}+\mathrm{e}_{\mathrm{it}}
\end{aligned}
$$

Hasil yang diperoleh dari model pada persamaan yaitu:

1. Jika TK meningkat sebesar $1 \%$ maka secara rata-rata, $\mathrm{PE}$ akan naik sebesar $24,8169 \%$.

2. Jika IPM meningkat sebesar $1 \%$ maka secara rata-rata, $\mathrm{PE}$ akan naik sebesar $28,5959 \%$. 
3. Jika $\mathrm{K}$ meningkat sebesar $1 \%$ maka secara rata-rata, PE akan turun sebesar 22,9780\%.

\section{Tabel 1}

\section{Hasil Uji Regresi}

\begin{tabular}{cccc}
\hline No. & Variabel & Signifkansi & Keterangan \\
\hline 1 & $\mathrm{X} 1$ & 0.0001 & Signifikan \\
\hline 2 & $\mathrm{X} 2$ & 0.0000 & Signifikan \\
\hline 3 & $\mathrm{X} 3$ & 0.0000 & Signifikan
\end{tabular}

Sumber: data diolah

Dari hasil tersebut maka variabel tenaga kerja dan Indeks Pembangunan Manusia (IPM) memiliki pengaruh yang positif dan signifikan terhadap pertumbuhan ekonomi. Variabel kemiskinan memiliki pengaruh yang negatif signifikan terhadap pertumbuhan ekonomi. Tenaga kerja yang terserap dalam lapangan pekerjaan dengan kondisi IPM yang baik di setiap kabupaten dan kota maka menjadi faktor utama dalam meningkatkan pertumbuhan ekonomi. Tenaga kerja dan IPM yang baik dapat mengurangi kemiskinan sehingga meningkatkan pertumbuhan ekonomi di kabupaten dan kota.

\section{Koefisien Determinasi $\left(\mathrm{R}^{2}\right)$}

Hasil dari pengolahan data diperoleh nilai koefisien determinasi $\left(\mathrm{R}^{2}\right)$ sebesar 0,917169 . Hasil ini menunjukkan bahwa nilai output sebagai variabel terikat dalam model penelitian ini dapat dijelaskan sebesar $91,71 \%$ oleh variabel bebas dalam model penelitian, sedangkan sisanya dipengaruhi oleh variabel-variabel lain diluar model pada penelitian sebesar 0,082831 atau $8,28 \%$. Variabel lain diluar penelitian merupakan kondisi sosial lainnya yang berada di masingmasing daerah tersebut yang mempengaruhi pertumbuhan ekonominya misalnya meliputi kondisi jalan, sistem pemerintahan, cuaca dan budaya.

\section{Uji F dan Uji t}

Pembuktian pengaruh variabel bebas secara bersama-sama terhadap variabel terikat dilakukan dengan menggunakan uji $\mathrm{F}$ dengan tingkat derajat keyakinan $(\alpha=5 \%)$. Angka dari hasil perhitungan menunjukkan $F_{\text {hitung }}>F_{\text {tabel, }}$ sehingga menunjukkan Ho ditolak dan $\mathrm{H}_{1}$ diterima dengan nilai probabilitas (F-statistik) sebesar 0,000000. Hasil ini menunjukkan secara bersama-sama variabel bebas mampu berpengaruh secara signifikan terhadap pertumbuhan ekonomi di kabupaten dan kota di Provinsi Jawa Timur tahun 2014-2018.

Dalam kondisi ini tenaga kerja harus terserap ke lapangan pekerjaan dan bekerja dengan mendapatkan upah yang sesuai dengan peraturan pemerintah, sehingga secara langsung mengurangi jumlah pengangguran dan mengurangi jumlah kemiskinan. Tenaga kerja yang bekerja harus memiliki pendidikan dan keterampilan dan semangat bekerja untuk meningkatkan produktivitas terhadap tenaga kerja tersebut dan produktivitas dalam memproduksi barang dan jasa. Barang dan jasa yang telah diproduksi akan dijual di pasar sehingga dapat dibeli oleh konsumen dengan harga tertentu. Banyaknya barang dan jasa yang telah diproduksi menunjukkan peran tenaga kerja dalam bekerja dan kondisi tenaga kerja dengan tingkat IPM meliputi kondisi pendidikan, kesehatan, kesejahteraan yang baik. Banyaknya masyarakat yang membeli barang dan jasa yang telah dijual di pasar menunjukkan kemampuan penghasilan yang baik di setiap orang di masyarakat daerah tersebut. Tentunya barang dan jasa yang telah diproduksi dan dijual di pasar untuk dibeli oleh masyarakat akan melalui proses distribusi terlebih dahulu. Proses distribusi barang dan jasa bisa melalui jalur darat, jalur laut dan jalur udara sehingga tentunya membutuhkan mesin dan peralatan transportasi untuk mengangkut dan menyalurkan barang dan jasa.

Tabel 2

Hasil Uji t

\begin{tabular}{ccc}
\hline Variabel Bebas & Hasil & Kesimpulan \\
\hline Tenaga Kerja & 0,0001 & Signifikan \\
\hline IPM & 0,0000 & Signifikan \\
\hline Kemiskinan & 0,0000 & Signifikan \\
\hline
\end{tabular}

Sumber: data diolah

Kondisi pertumbuhan ekonomi yang baik di setiap daerah digambarkan dengan kondisi tenaga kerja yang memiliki pendidikan dan kesehatan yang baik, lalu dimana tenaga kerja tersebut terserap di lapangan pekerjaan sehingga tidak banyak pengangguran, tenaga kerja memiliki penghasilan yang digunakan untuk memenuhi kebutuhan hidup dan menabung sehingga secara jangka panjang akan mengurangi kemiskinan, masalah kemiskinan harus sekecil dan sedikit karena kemiskinan yang parah akan menyebabkan masalah di perekonomian dan masalah sosial lainnya di setiap daerah. 


\section{Pembuktian Hipotesis}

1. Penelitian ini menjawab hipotesis pertama yaitu variabel bebas tenaga kerja, IPM, kemiskinan berpengaruh secara parsial terhadap variabel terikat pertumbuhan ekonomi selama tahun 2014-2018 di kabupaten dan kota di Jawa Timur.

2. Penelitian ini menjawab hipotesis kedua yaitu variabel bebas tenaga kerja, IPM, kemiskinan berpengaruh secara simultan terhadap variabel terikat pertumbuhan ekonomi selama tahun 2014-2018 di kabupaten dan kota di Jawa Timur.

\section{PENUTUP}

\section{Kesimpulan}

Variabel bebas tenaga kerja, Indeks Pembangunan Manusia (IPM) dan kemiskinan berpengaruh secara parsial terhadap variabel terikat pertumbuhan ekonomi selama tahun 20142018 di kabupaten dan kota di Jawa Timur.

Variabel bebas tenaga kerja, Indeks Pembangunan Manusia (IPM) dan kemiskinan berpengaruh secara simultan terhadap variabel terikat pertumbuhan ekonomi selama tahun 20142018 di kabupaten dan kota di Jawa Timur.

\section{Keterbatasan dan Rekomendasi Untuk Penelitian Selanjutnya}

Pemerintah meningkatkan laju pertumbuhan ekonomi dan mempertahankan kondisi pertumbuhan ekonomi tetap dalam kondisi stabil dengan cara:

1. Meningkatkan kualitas penduduk. Cara yang dilakukan adalah memberikan pelayanan kesehatan berupa Rumah Sakit, Puskesmas dan Posyandu.

2. Meningkatkan kualitas tenaga kerja. Cara yang dilakukan dengan memberikan pelatihan kerja dan magang bagi para lulusan SMA dan Perguruan Tinggi, memberikan asuransi ketenaga kerjaan bagi pekerja pemerintahan dan swasta, memberikan gaji sesuai dengan upah minimum kota dan kabupaten.
3. Mengurangi kemiskinan. Cara yang dilakukan memberikan bantuan uang tunai bagi keluarga miskin, memberikan pinjaman mudah bagi pedagang UKM dan UMKM melalui bank dan lembaga keuangan bukan bank lainnya.

Melibatkan swasta untuk meningkatkan laju pertumbuhan ekonomi dan mempertahankan kondisi pertumbuhan ekonomi tetap dalam kondisi stabil dengan cara:

1. Membuka lahan pekerjaan baru.

2. Memberikan pelatihan bagi tenaga kerja

3. Memberikan bantuan berupa barang dan bantuan keuangan melalui pemerintah untuk masyarakat.

\section{DAFTAR PUSTAKA}

BPS, 2010, Analisis Indikator Makro Sosial dan Ekonomi Kabupaten/Kota Provinsi Jawa Timur. Badan Pusat Statistik Jawa Timur.

Randall, Jones, S. Income Inequality, Poverty, Social Spending in Japan. ECO/WKP (2007)16. Economics Department Working Papers No.556. Organisation for Economic Co-Operation and Development.

Sajid, A. 1998. Size of the Government, Welfare and Labour Supply in the Presence of Variable Returns. Darwin NT 0909, Australia. Faculty of Business, Northern Territory University.

Sugiyono. 2012. Metode Penelitian Kuantitatif Kualitatif. Bandung. Alfa Beta.

Todaro dan Smith, Stephen C. 1998. Pembangunan Ekonomi. Jakarta: Erlangga.

Werner. 2008. Tax Burden, Government Expenditure and Income Distribution in Brazil. The Quartely Review of Economics and Finance. Elsevier. University of Illinois at Urbana-Champaign: US.

Widarjono, A. 2007. Ekonometrika Teori. LPFE UII. 